\title{
Effects of the green macroalga Enteromorpha intestinalis on macrobenthic and seagrass assemblages in a shallow coastal estuary
}

\author{
S. P. Cummins ${ }^{1,2,4, *}$, D. E. Roberts ${ }^{1,3}$, K. D. Zimmerman ${ }^{1}$ \\ ${ }^{1}$ School of Science \& Technology, University of Newcastle, Ourimbah, New South Wales 2258, Australia \\ ${ }^{2}$ Wyong Shire Council, PO Box 20, Wyong, New South Wales 2250, Australia \\ ${ }^{3}$ Bioanalysis, 7 Berry's Head Road, Narara, New South Wales 2250, Australia \\ ${ }^{4}$ Present address: Centre for Research on Ecological Impacts of Coastal Cities, Marine Ecology Laboratories, A11, \\ University of Sydney, Sydney, New South Wales 2006, Australia
}

\begin{abstract}
A common symptom of eutrophication in temperate estuaries is the proliferation of ephemeral, floating macroalgae. Information on the effects of blooms on underlying assemblages mostly originates from non-vegetated intertidal and subtidal habitats. Blooms also often settle in large aggregations over seagrasses, where they decompose. To test hypotheses concerning the effect of dense mats on underlying assemblages of benthic invertebrates within a seagrass meadow, biomass of the green macroalga Enteromorpha intestinalis was experimentally manipulated in the Tuggerah Lakes estuary, New South Wales, Australia. Algae, equivalent to a naturally occurring bloom $\left(\sim 4.5 \mathrm{~kg}\right.$ wet wt $\left.\mathrm{m}^{-2}\right)$, were added to caged plots $\left(1 \mathrm{~m}^{2}\right)$ at 2 sites in the seagrass meadow. After $3 \mathrm{mo}$, the E. intestinalis population began to decompose in the treatment plots and in shallow habitats adjacent to the foreshore. Dramatic declines in the biomass of seagrass and components of the infauna were detected in plots containing decomposing macroalgae. The results have implications for managing estuaries, since assemblages of seagrasses and macrobenthic organisms are considered to be important in nutrient-cycling and food-webs.
\end{abstract}

KEY WORDS: Macroalgae $\cdot$ Bloom $\cdot$ Seagrass $\cdot$ Macrobenthos $\cdot$ Eutrophication Resale or republication not permitted without written consent of the publisher

\section{INTRODUCTION}

There is much interest in the effect of excessive growth or 'blooms' of unattached macroalgae in estuarine systems worldwide. Blooms of these algae occur naturally in estuaries, but have increased in their frequency, magnitude and persistence in many areas, particularly in shallow systems with limited tidal exchange (Raffaelli et al. 1998). These changes are thought to be a symptom of eutrophication (Lavery et al. 1991, Sfriso et al. 1992, Kinney \& Roman 1998, Raffaelli et al. 1998). Information on the effects of blooms to underlying assemblages originates mainly from studies on non-vegetated intertidal (Hull 1987, Bolam et al. 2000) or subtidal (Thrush 1986, Ólafsson
1988, Everett 1994, Norkko \& Bonsdorff 1996a) habitats. Declines in seagrass in some estuaries are also thought to be related to blooms of opportunistic macroalgae (Williams Cowper 1978, Shepherd et al. 1989, Holmquist 1997, Raffaelli et al. 1998).

Seagrass meadows commonly support more diverse and abundant assemblages of fauna than do the surrounding areas of unvegetated sediments (Orth 1973, Stoner 1980, Peterson 1982, Edgar 1990, Ferrell \& Bell 1991, Boström \& Bonsdorff 1997). One explanation for this pattern is that the physical structure of seagrass modifies the local environment relative to surrounding areas, by increasing complexity important to fauna (e.g. Edgar \& Robertson 1992), reducing watermovement (Gambi et al. 1990, Boström \& Bonsdorff 
2000), trapping sediments, larvae and food (Grady 1981, Peterson et al. 1984, Boström \& Bonsdorff 2000) and providing protection from predators (Peterson 1982, Boström et al. 2002). Increasing loss and fragmentation of seagrass habitat is causing growing concern, as it is considered to be of great importance for the ecology and productivity of coastal waters (Orth et al. 1984, Anderson 1989, Edgar et al. 1994, Edgar \& Shaw 1995, Boström \& Bonsdorff 2000).

Unattached macroalgae make important contributions to the structural complexity of seagrass meadows. Clumps of macroalgae often contain large numbers of fauna and can facilitate their dispersal as they are propelled across the landscape by water-currents (Holmquist 1994, Brooks \& Bell 2001). Holmquist (1994) showed that drift macroalgae $(25 \mathrm{~cm}$ in diameter) were efficient transporters of several species of molluscs, decapods, ophiuroids and fishes, sometimes moving up to $0.5 \mathrm{~km}$ in a day. This would effectively decrease the degree of isolation between fragments of seagrass within a landscape, particularly for fauna lacking planktonic larval stages (Holmquist 1994, 1998, Brooks \& Bell 2001). Any positive contribution that drifting clumps may make to seagrass communities can, however, be offset if the algae coalesce into large, stationary mats (Holmquist 1994). In a related study, Isaksson \& Pihl (1992) observed a reduction in the total abundance and biomass of epibenthic fauna in response to heavy overgrowth of seagrass by filamentous algae. Moreover, future blooms often develop, once bloom-forming algae become established at a site (Raffaelli et al. 1998).

Manipulative experiments by Holmquist (1997) and Hauxwell et al. (2001) demonstrated that overlying clumps of macroalgae can create sizeable gaps in a seagrass canopy. Recovery of seagrasses after a disturbance is often slow (Holmquist 1997, Butler \& Jernakoff 1999, Hauxwell et al. 2001). Whilst the algae can provide an alternative structure for many fauna, species of drift macroalgae are often ephemeral (i.e. persisting for months; Virnstein \& Carbonara 1985, Sogard \& Able 1991, Holmquist 1997). Changes in the availability and spatial distribution of the seagrass habitat ultimately affect the structure and function of the seagrass landscape (Stamps et al. 1987, Wiens 1992, Boström \& Bonsdorff 2000, Brooks \& Bell 2001). Disturbances that affect the distribution of the seagrass habitat can greatly affect associated fauna (Heck \& Thoman 1981, Worthington et al. 1991, Doak et al. 1992, Skilleter 1994, Holmquist 1997, Eggleston et al. 1999, Boström \& Bonsdorff 2000).

In addition to destroying the primary habitat of the majority of seagrass-associated species, the decomposition of clumps can alter the physical characteristics of the underlying sediments. The handful of studies that have directly examined the effects of such events on animals associated with seagrasses have focused on mobile fauna (e.g. Holmquist 1997). Results from studies examining the effects of decomposing algae on assemblages of benthic macroinvertebrates in unvegetated habitats have been equivocal. A number of factors may be attributed to the differences in responses: differences in biomass or species composition of macroalgae, hydrological regimes, characteristics of the sediments, and in the spatial and temporal scales examined (Raffaelli et al. 1998). For example, breakdown of small amounts of macroalgal material may stimulate production of many deposit-feeders, but larger amounts may reduce oxygen concentrations and cause migration or mortality (Hull 1987, Norkko \& Bonsdorff 1996a, Hansen \& Kristensen 1997). Consequently, studies examining their specific effects on seagrass and associated fauna are required.

Herein we expand on this topic by quantifying the effects of large stationary clumps of macroalgae on assemblages in a seagrass meadow near Sydney, Australia. Based on observations from the literature and in the field, we hypothesised that the formation and subsequent decomposition of persistent clumps of macroalgae cause decreases in the biomass of the underlying seagrasses and alter the structure of assemblages of benthic macroinvertebrates. Specifically, we hypothesised that small-scale experimental 'blooms' would have similar effects, and tested this by applying bloomsized densities of the drift species Enteromorpha intestinalis to experimental plots in a seagrass meadow. E. intestinalis was chosen because it was abundant at the time of the study, and because it is a common bloom forming species in Australia and worldwide (King \& Hodgson 1995, Raffaelli et al. 1998). Seagrass and infauna in plots to which algae were added and those in control plots were sampled after 3 mo, i.e. after the E. intestinalis population had begun to decompose on the surface.

\section{MATERIALS AND METHODS}

Location. The study was done in a seagrass meadow in the Tuggerah Lakes estuary on the central coast of New South Wales, Australia (Fig. 1). The estuary has a surface area of $75 \mathrm{~km}^{2}$ and is open to the sea the entrance via a narrow channel, which allows limited $(<1 \%)$ tidal exchange and a tidal amplitude of approx. $0.1 \mathrm{~m}$ (King \& Hodgson 1995, Roberts 2001). The sediments vary between sandy mud (50 to $95 \%$ mud) and muddy sand (5 to $50 \%$ mud; Roberts 2001). Massive and persistent (i.e. over a period of months) blooms of drift macroalgae, usually of the genera Enteromorpha, Chaetomorpha and Cladophora (class Chlorophyta) 


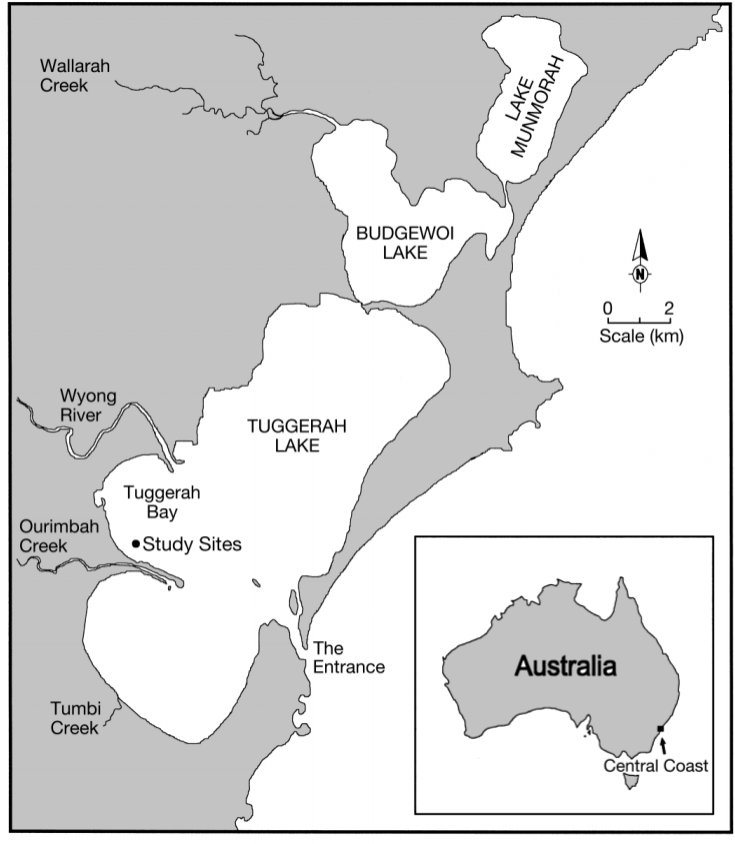

Fig. 1. Tuggerah Lakes estuary, central coast of New South Wales, Australia

are common in several areas, often developing rapidly and then settling over seagrass meadows or accumulating along the foreshore, where they decompose (King \& Hodgson 1995, Roberts 2001).

At the time of the study, the seagrass meadow was composed of Halophila ovalis (R. Brown), Zostera capricorni (Ascherson) and Ruppia megacarpa (Mason) $(63 \pm 10 \%, 21 \pm 8 \%$ and $16 \pm 6 \%$ of the total biomass, respectively; $\mathrm{n}=10$ ). Interspersed amongst the seagrasses were Chondria succulenta (J. Agardh) Falkenberg, Chaetomorpha linum (O. F. Müller) Kützing, Microdictyon umbilicatum (Velley) Zanardini, Enteromorpha intestinalis and Gracilaria edulis (Gmelin) Silva in very low densities $\left(<5 \mathrm{~g}\right.$ wet $\left.\mathrm{wt}^{-2}\right)$. A dense band (approximately 15 to $20 \mathrm{~m}$ wide) of E. intestinalis was present in the shallow $(<20 \mathrm{~cm})$ unvegetated area adjacent to the shoreline.

Experimental design. To test the hypotheses that small-scale experimental 'blooms' would cause declines in the biomass of the underlying seagrasses and alter the structure of assemblages of benthic macroinvertebrates, bloom-sized densities of Enteromorpha intestinalis were applied to experimental plots in a seagrass meadow. To secure the macroalgae, wire mesh was used to fence off plots $(1 \times 1 \mathrm{~m}$ and $0.9 \mathrm{~m}$ high $)$ within the seagrass meadow. The $1.5 \times 1.5 \mathrm{~cm}$ mesh-size of the wire was small enough to retain the macroalgae, but sufficiently large to ensure that water circulation was not restricted significantly. The bottom edges of each fence were raised to $10 \mathrm{~cm}$ above the substratum, allowing macrobenthic organisms to move in and out of the plots. Plots were chosen randomly within 2 sites (each approx. $25 \times 20 \mathrm{~m}$, and $50 \mathrm{~m}$ apart) located $100 \mathrm{~m}$ from the shore at a depth of 0.5 to $1.0 \mathrm{~m}$. To test for possible confounding effects of the fences, various procedural controls were used. The experiment involved 4 treatments: (1) algal addition (AA), whereby E. intestinalis was added to fenced plots; (2) untouched controls (UC), which were undisturbed areas haphazardly chosen in the seagrass meadow; (3) a fenced control (FC), whereby panels were removed to allow animals such as fishes free access, thus controlling for the effect of the fenced structures (no algae were added); (4) an exclusion control (EC), whereby fences were intact, to control for the effect of the fenced structures and the exclusion of movement of animals in and out (no algae were added).

There were 5 replicates of each treatment (AA, UC, FC, EC) at each site. Enteromorpha intestinalis was collected from nearshore areas and added to AA plots in August 1999, at a weight and cover equivalent to those in seagrasses in some areas in the estuary or equivalent to those close to the shore at the study location (a $15 \mathrm{~cm}$ thick algal mat $\sim 4.5 \mathrm{~kg}$ wet wt $\mathrm{m}^{-2}$ or $\sim 0.45 \mathrm{~kg}$ dry wt $\mathrm{m}^{-2}$, respectively). Large numbers of the hydrobiid gastropod Potamopyrgus antipodarum (Gray) and species of epifaunal amphipods and isopods were present in the algae added to the plots. These animals were not removed, since dispersal of benthic organisms via clumps of drift macroalgae occurs naturally (Holmquist 1994) and it was considered important to disturb the alga as little as possible.

The sites were visited weekly to assess the condition and cover of the macroalgae in each of the AA treatment plots and to ensure that the fenced structures had not trapped drift algae. Structural breakdown of the Enteromorpha intestinalis population began in experimental plots and adjacent to the foreshore after $11 \mathrm{wk}$. The plots were left for a further week, during which breakdown of the algae occurred rapidly, and then sampled using a corer $(10 \mathrm{~cm}$ diameter, $10 \mathrm{~cm}$ deep). We collected 1 core sample from the centre (to avoid possible edge effects) of each of the replicate treatment (AA, UC, FC, EC) plots at each site. Samples were collected by carefully penetrating the plant material and sediment with the corer, which was then capped to create sufficient suction to retain the sample. Samples were sieved through a $0.5 \mathrm{~mm}$ mesh, placed into labelled plastic bags, fixed with $7 \%$ buffered formalin/seawater (v/v), and then sorted under a binocular microscope. Above-ground parts of seagrasses were sorted to species and oven-dried to a constant weight at $105^{\circ} \mathrm{C}$ for $48 \mathrm{~h}$ prior to weighing to the nearest $0.01 \mathrm{~g}$. Polychaetes were identified and 
enumerated as families, bivalves and gastropods were identified to species. Other faunal groups counted were oligochaetes, infaunal amphipods, nemerteans, platyhelminths and anthozoans. Warwick (1988), James et al. (1995) and Chapman (1998) found that, whilst analyses at family level were weighted by the pattern of the most abundant species of benthic fauna, similar patterns in assemblages occurred irrespective of the level of taxonomic resolution used, justifying the use of taxonomic levels higher than species for some organisms in our study.

Data analysis. The PRIMER software package (Plymouth Marine Laboratory) was used to test hypotheses about multivariate differences among assemblages of macrofauna. Nonmetric multidimensional scaling (nMDS) ordinations of all replicates were plotted based on non-transformed abundances and Bray-Curtis similarities; 1-way analyses of similarities (ANOSIM; Clarke \& Warwick 1994) tested for differences in the structure of assemblages among treatments within each site. The percentage contributions of taxa to dissimilarities between pairs of treatments within sites were calculated using the SIMPER program (Clarke \& Warwick 1994). Differences in abundances of selected variables collected from core samples were tested by 2 -factor analyses of variance. Treatment (4 levels) was fixed and site (2 levels) was random. Data were examined for het- erogeneity of variances using Cochran's C-test and means were compared by Student-Newman-Keuls (SNK) tests.

\section{RESULTS}

Following cover by Enteromorpha intestinalis for almost 3 mo and then rapid breakdown of the algae, there were considerable differences in the rank abundance of major taxonomic groups between algal addition (AA) and control (UC, FC, EC) treatments (Table 1). Polychaetes were most abundant in control plots, whilst gastropods were numerically dominant in plots to which macroalgae had been added (Table 1). Larger taxa or deeper burrowing forms, such as orbiniid polychaetes, the bivalve Tellina deltoidalis Lamarck and the gastropod Batillaria australis (Quoy \& Gaimard), were present in small numbers in control plots, but were generally absent from AA plots. The vertical sediment profiles of core samples collected from AA treatment plots were black to a few centimetres below the surface and had a strong hydrogen sulphide odour typical of anoxic sediments. Mean $( \pm \mathrm{SE} ; \mathrm{n}=5)$ biomass estimates ( $\mathrm{g}$ dry wt core $^{-1}$ ) of E. intestinalis collected from core samples at each of the 2 sites were $0.92( \pm 0.41)$ and $0.94( \pm 0.41)$, respectively.
Table 1. Percentage (mean $\pm \mathrm{SE} ; \mathrm{n}=5$ plots) of different macrofaunal taxa in experimental plots at each site. AA: algal addition; UC: untouched control; FC: fenced control; EC: exclusion control

\begin{tabular}{|lrrrcrrrr|}
\hline \multirow{2}{*}{ Taxon } & \multicolumn{9}{c}{ Site 1 } & \multicolumn{4}{c|}{ Site 2} \\
& AA & UC & FC & EC & AA & UC & FC & EC \\
\hline Polychaetes & $14 \pm 5$ & $54 \pm 5$ & $43 \pm 4$ & $44 \pm 6$ & $20 \pm 17$ & $71 \pm 3$ & $47 \pm 7$ & $57 \pm 4$ \\
Gastropods & $72 \pm 8$ & $13 \pm 3$ & $35 \pm 5$ & $29 \pm 10$ & $73 \pm 19$ & $11 \pm 1$ & $27 \pm 7$ & $13 \pm 3$ \\
Bivalves & $10 \pm 3$ & $19 \pm 5$ & $13 \pm 4$ & $14 \pm 7$ & $5 \pm 2$ & $12 \pm 2$ & $12 \pm 4$ & $19 \pm 1$ \\
Crustaceans & $1 \pm 1$ & $12 \pm 4$ & $7 \pm 2$ & $10 \pm 3$ & $<1 \pm 0$ & $5 \pm 1$ & $11 \pm 2$ & $9 \pm 2$ \\
Other & $3 \pm 2$ & $2 \pm 1$ & $2 \pm 1$ & $2 \pm 1$ & $1 \pm 1$ & $1 \pm 0$ & $3 \pm 1$ & $3 \pm 1$ \\
\hline
\end{tabular}

Table 2. Summary of mean Bray-Curtis dissimilarity values (untransformed data) and results of ANOSIM tests of differences in structure of assemblages of macrobenthic organisms among treatments within each site. Abbreviations as in Table 1. ns: not significant; ${ }^{*}$ significant at $\mathrm{p}<0.05 ;{ }^{* *}$ significant at $\mathrm{p}<0.01$

\begin{tabular}{|lccccccccc|}
\hline & \multicolumn{4}{c}{ Site 1 } & \multicolumn{4}{c}{ Site 2 } \\
& AA & UC & FC & EC & AA & UC & FC & EC \\
\hline Within samples & 50 & 37 & 35 & 47 & 66 & 30 & 37 & 31 \\
Between samples & & & & & & & & \\
AA & & $67^{* *}$ & $50^{*}$ & $57^{*}$ & & $82^{*}$ & $74^{*}$ & $81^{*}$ \\
UC & & & $41_{\text {ns }}$ & $42_{\text {ns }}$ & & & $38_{\text {ns }}$ & $33_{\text {ns }}$ \\
FC & & & & & & & & & $38_{\text {ns }}$ \\
\hline
\end{tabular}

\section{Multivariate analysis}

The macrofauna assemblages differed significantly between $\mathrm{AA}$ and control treatments UC, FC, EC at each site (ANOSIM; Table 2). Pairwise comparisons revealed no significant differences among the control treatments at either site (Table 2), indicating no effects of the experimental procedure on infauna. This pattern was illustrated by a 2-dimensional ordination plot (nMDS; Fig. 2a).

There appeared to be greater variability in the structure of assemblages among AA plots than among replicate control plots (see Fig. 2a). Warwick \& Clarke (1993) proposed that disturbance increases variation in assemblages at different spatial scales, although Chapman et al. (1995) found the opposite. To test formally the hypothesis that addition of algae significantly altered the variability in assemblages among replicates, Bray-Curtis measures of dissimilarity were calcu- 
Table 3. Summary of SIMPER analyses indicating rank (1 to 5 presented only) and percentage contributions (in parentheses) of taxa to dissimilarities between pairs of treatments within each site $(1=$ taxon that contributed most to difference). Abbreviations as in Table 1. -: no data

\begin{tabular}{|c|c|c|c|c|c|c|c|c|c|c|c|c|}
\hline \multirow[t]{2}{*}{ Taxon } & \multicolumn{6}{|c|}{ Site 1} & \multicolumn{6}{|c|}{ Site 2} \\
\hline & $\begin{array}{c}\text { AA vs } \\
\text { UC }\end{array}$ & $\begin{array}{c}\text { AA vs } \\
\text { FC }\end{array}$ & $\begin{array}{c}\text { AA vs } \\
\text { EC }\end{array}$ & $\begin{array}{c}\mathrm{UC} \text { vs } \\
\text { FC }\end{array}$ & $\begin{array}{c}\mathrm{UC} \text { vs } \\
\mathrm{EC}\end{array}$ & $\begin{array}{c}\mathrm{FC} \text { vs } \\
\mathrm{EC}\end{array}$ & $\begin{array}{l}\text { AA vs } \\
\text { UC }\end{array}$ & $\begin{array}{c}\text { AA vs } \\
\text { FC }\end{array}$ & $\begin{array}{c}\text { AA vs } \\
\text { EC }\end{array}$ & $\begin{array}{c}\mathrm{UC} \text { vs } \\
\mathrm{FC}\end{array}$ & $\begin{array}{c}\mathrm{UC} \text { vs } \\
\mathrm{EC}\end{array}$ & $\begin{array}{c}\mathrm{FC} \text { vs } \\
\mathrm{EC}\end{array}$ \\
\hline \multicolumn{13}{|l|}{ Polychaetes } \\
\hline Capitellidae & $4(8)$ & $3(13)$ & $2(11)$ & $3(14)$ & $4(14)$ & $2(15)$ & $3(12)$ & $2(11)$ & $3(11)$ & $3(15)$ & $3(13)$ & $4(15)$ \\
\hline Nereididae & - & - & - & - & - & - & - & - & - & - & - & $5(7)$ \\
\hline Opheliidae & $2(11)$ & $2(15)$ & $3(10)$ & $4(11)$ & $3(14)$ & $4(14)$ & $2(12)$ & $3(7)$ & $2(12)$ & $2(23)$ & $1(26)$ & $2(21)$ \\
\hline \multicolumn{13}{|l|}{ Amphipods } \\
\hline Infaunal amphipods & $5(7)$ & $5(6)$ & $4(7)$ & $5(8)$ & $5(9)$ & $5(7)$ & - & $4(6)$ & $5(5)$ & $4(11)$ & $5(10)$ & - \\
\hline \multicolumn{13}{|l|}{ Gastropods } \\
\hline Potamopyrgus antipodarum & $1(49)$ & $1(46)$ & $1(54)$ & $1(35)$ & $1(24)$ & $1(36)$ & $1(63)$ & $1(64)$ & $1(57)$ & $1(28)$ & $4(14)$ & $1(21)$ \\
\hline \multicolumn{13}{|l|}{ Bivalves } \\
\hline Arthritica helmsi & $3(9)$ & $4(8)$ & $5(6)$ & $2(15)$ & $2(19)$ & $3(14)$ & $4(3)$ & $5(5)$ & $4(7)$ & $5(9)$ & $2(19)$ & $3(17)$ \\
\hline
\end{tabular}

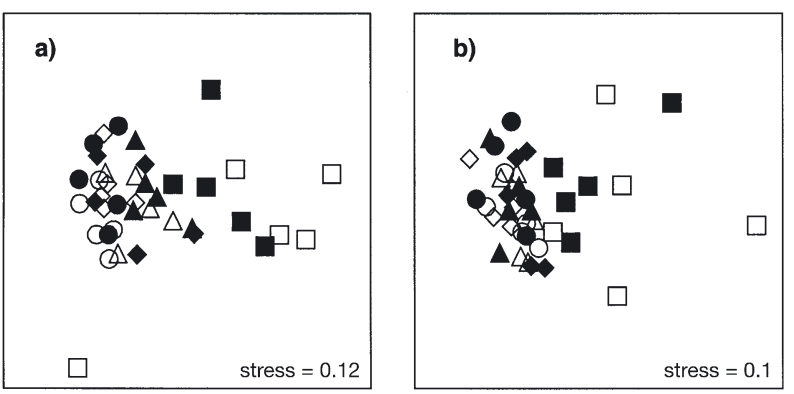

Fig. 2. Non-metric multidimensional scaling (nMDS) ordination of (a) all taxa and (b) all taxa excluding gastropod Potamopyrgus antipodarum, based on non-transformed abundances and Bray-Curtis similarities ( $\mathrm{n}=5$ cores). Squares: algal addition; circles: untouched control; triangles: fenced control; diamonds: exclusion control; closed symbols: Site 1; open symbols: Site 2

lated between 2 pairs of replicates from each treatment for each site (see Underwood \& Chapman 1998). This gave $\mathrm{n}=2$ independent measures of percentage dissimilarity. There was no significant (ns) difference in variability among each of the 4 treatments $(F=0.57 \mathrm{~ns}$, $\mathrm{df}=3,3, \mathrm{p}<0.05)$. Although there were few replicates, the lack of significance probably reflects no difference, rather than being a lack of power, since variation among treatments was not much larger than the variation among samples.

Dissimilarities among treatments were due primarily to differences in the relative abundances of taxa rather than the presence or absence of specific taxa (SIMPER; Table 3). Potamopyrgus antipodarum contributed most to differences between AA plots and control plots; the abundances of all other ranked species were con- siderably smaller in AA plots than in control plots. $P$. antipodarum also contributed to dissimilarities among control treatments, due to it being consistently more abundant in FC and EC plots than in UC plots at both sites, possibly indicating that the snails were attracted to the caged structures, or that the cages provided some protection from predation. The percentage contributions of taxa ranked as contributing most to dissimilarities among control treatments were relatively small, either because most taxa had similar densities or because they were sparse and patchy (Table 3). Given the relatively great importance of $P$. antipodarum in differences among treatments, and that it was probably introduced into the habitat with the algae, assemblages were analysed without the data for this snail. The results were essentially the same as those achieved when the snail was included (Fig. 2b; Table 4).

\section{Populations analysis}

The biomass of the seagrass was drastically reduced in plots to which macroalgae had been added compared to control plots at each site $(\mathrm{AA}<\mathrm{UC}, \mathrm{EC}, \mathrm{FC}$; Fig. 3;

Table 4. Summary of mean Bray-Curtis dissimilarity values (untransformed data) and results of ANOSIM tests of differences in structure of assemblages of macrobenthic organisms among treatments within each site, with Potamopyrgus antipodarum omitted. Further details as in Table 2

\begin{tabular}{|lcccccccc|}
\hline & \multicolumn{4}{c}{ Site 1 } & \multicolumn{4}{c|}{ Site 2 } \\
& AA & UC & FC & EC & AA & UC & FC & EC \\
\hline Within samples & \multirow{2}{*}{52} & 40 & 37 & 44 & 68 & 30 & 36 & 31 \\
Between samples & & & & & & & & \\
AA & & $59^{*}$ & $57^{*}$ & $53_{\mathrm{ns}}$ & & $67^{* *}$ & $66^{* *}$ & $71^{* *}$ \\
UC & & & $36_{\mathrm{ns}}$ & $41_{\mathrm{ns}}$ & & & $34_{\mathrm{ns}}$ & $34_{\mathrm{ns}}$ \\
FC & & & $37_{\mathrm{ns}}$ & & & & $34_{\mathrm{ns}}$ \\
\end{tabular}




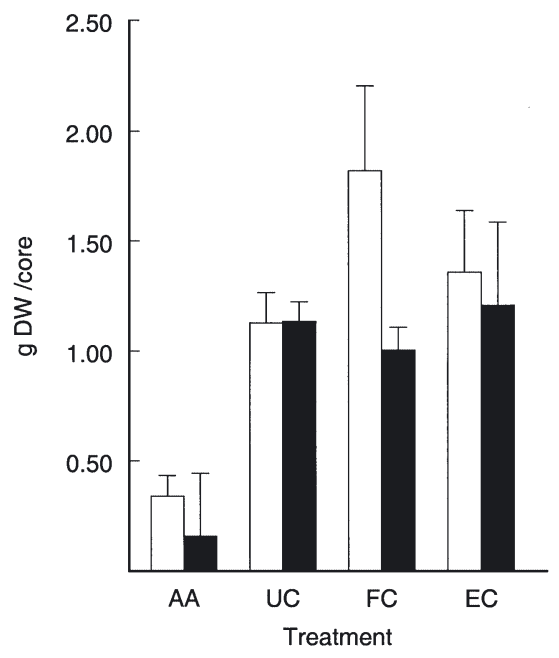

Fig. 3. Mean ( $+\mathrm{SE} ; \mathrm{n}=5$ cores) biomass estimates ( $\mathrm{g}$ dry $\mathrm{wt}$ $\mathrm{cor}^{-1}$ ) of seagrass collected from each of 2 sites (open bars: Site 1; closed bars: Site 2) for each treatment. AA: algal addition, UC: untouched control, FC: fenced control; EC: exclusion control

Table 5). This is consistent with the prediction that static accumulations of macroalgae can cause loss of aboveground structure and biomass of underlying seagrass.

There were fewer taxa in the plots to which algae had been added (AA < UC, EC, FC; Fig. 4a; Table 5). The gastropod Potamopyrgus antipodarum was significantly more abundant in AA plots than in any control plot, and accounted for over $70 \%$ of the individuals collected (AA > UC, EC, FC; Fig. 4b; Tables 1 \& 5). This species is often extremely abundant in disturbed habi- tats (Walker 1998), and was present in large numbers amongst the Enteromorpha intestinalis when the latter was added to the experimental plots.

Polychaete worms were the most abundant component of infaunal assemblages in control plots, but their numbers were significantly lower in AA plots at both sites than in control plots (AA < UC, FC, EC; Fig. 4c; Tables $1 \& 5$ ). The mean numbers of the component families Capitellidae (AA < UC, FC, EC), Spionidae $(\mathrm{AA}<\mathrm{UC}, \mathrm{FC}, \mathrm{EC})$ and Orbiniidae $(\mathrm{AA}<\mathrm{UC}, \mathrm{FC}, \mathrm{EC})$ (Fig. $4 \mathrm{~d}, \mathrm{e}, \mathrm{f}_{i}$ Table 5) reflected this pattern. Although Opheliidae and Nereididae were also considerably less abundant in AA plots, they were not significantly so (Fig. 4g,h; Table 5). Fewer bivalves (mostly of the species Arthritica helmsi [Hedley] [Family Galeommatidae]) and infaunal amphipods were found in AA plots, but their adundance did not vary significantly among treatments (Fig. 4i,j; Table 5).

\section{DISCUSSION}

In seagrass meadows, a variety of disturbances can create open patches. Few published studies have experimentally examined the direct effects of blooms of macroalgae, but it is clear that such events can greatly influence patterns in the distribution and abundance of seagrasses and assemblages of benthic infauna. Placing Enteromorpha intestinalis in plots in a seagrass meadow caused sizeable gaps in the seagrass canopy in addition to considerable declines in components of the benthic fauna. Polychaete worms were the

Table 5. Summary of analyses of variance for selected variables collected from core samples from manipulative field experiment $(\mathrm{n}=5)$. F-ratios in bold calculated after post-hoc pooling at $\mathrm{p}>0.25$ (Winer et al. 1991). Data were examined for heterogeneity of variance using Cochran's $C$-test and were untransformed unless specified. ns: not significant $(\mathrm{p}>0.05)$; ${ }^{*}$ significant at $\mathrm{p}<0.05$; ${ }^{* *}$ significant at $\mathrm{p}<0.01$. Treatment (4 levels) was fixed; site ( 2 levels) was random

\begin{tabular}{|c|c|c|c|c|c|c|c|c|c|c|c|c|c|}
\hline \multirow[t]{2}{*}{ Source of variation } & \multirow[b]{2}{*}{$\mathrm{df}$} & \multicolumn{2}{|c|}{$\begin{array}{l}\text { Seagrass } \\
\text { biomass }^{\mathrm{a}} \\
C=0.33_{\mathrm{ns}}\end{array}$} & \multicolumn{2}{|c|}{$\begin{array}{c}\text { No. of } \\
\text { taxa } \\
C=0.36_{\mathrm{ns}}\end{array}$} & \multicolumn{2}{|c|}{$\begin{array}{l}\text { Potamopyrgus } \\
\text { antipodarum } \\
C=0.88^{* *}\end{array}$} & \multicolumn{2}{|c|}{$\begin{array}{l}\text { Polychaetes }^{\mathrm{a}} \\
\qquad C=0.26_{\mathrm{ns}}\end{array}$} & \multicolumn{2}{|c|}{$\begin{array}{l}\text { Capitellidae } \\
\qquad C=0.18_{\text {ns }}\end{array}$} & \multicolumn{2}{|c|}{$\begin{array}{l}\text { Spionidae }^{\mathrm{a}} \\
C=0.33_{\mathrm{ns}}\end{array}$} \\
\hline & & MS & $F$ & MS & $F$ & MS & $F$ & MS & $F$ & MS & $F$ & MS & $F$ \\
\hline Treatment & 3 & 0.33 & $9.86^{*}$ & 30.03 & $7.19^{* *}$ & 124186 & $5.12^{* *}$ & 46.58 & $9.49^{*}$ & 1206 & $5.19^{* *}$ & 3.39 & $11.23^{* *}$ \\
\hline Site & 1 & 0.07 & $2.98_{\mathrm{ns}}$ & 0.23 & $0.05_{\mathrm{ns}}$ & 12145 & $0.50_{\mathrm{ns}}$ & 1.50 & $0.73_{\mathrm{ns}}$ & 456 & $1.96_{\mathrm{ns}}$ & 1.16 & $3.86_{\mathrm{ns}}$ \\
\hline Treatment $\times$ Site & 3 & 0.03 & $1.46_{\mathrm{ns}}$ & 3.36 & $0.80_{\mathrm{ns}}$ & 28438 & $1.17_{\mathrm{ns}}$ & 4.91 & $2.39_{\mathrm{ns}}$ & 162 & $0.70_{\mathrm{ns}}$ & 0.31 & $1.02_{\mathrm{ns}}$ \\
\hline \multirow[t]{3}{*}{ Residual } & 32 & 0.02 & & 4.25 & & 23843 & & 2.06 & & 239 & & 0.30 & \\
\hline & & \multicolumn{2}{|c|}{$\begin{array}{l}\text { Orbiniidae }^{\mathrm{a}} \\
C=0.34_{\mathrm{ns}}\end{array}$} & \multicolumn{2}{|c|}{$\begin{array}{c}\text { Opheliidae }^{\mathrm{a}} \\
C=0.27_{\mathrm{ns}}\end{array}$} & \multicolumn{2}{|c|}{$\begin{array}{l}\text { Nereididae }^{\mathrm{a}} \\
C=0.27\end{array}$} & \multicolumn{2}{|c|}{$\begin{array}{l}\text { Bivalves }^{\mathrm{a}} \\
C=0.31_{\mathrm{ns}}\end{array}$} & \multicolumn{2}{|c|}{$\begin{array}{l}\text { Infaunal amphipod }^{\text {a }} \\
\qquad C=0.24_{\text {ns }}\end{array}$} & & \\
\hline & $\mathrm{df}$ & MS & $F$ & MS & $F$ & MS & $F$ & MS & $F$ & MS & $F$ & & \\
\hline Treatment & 3 & 0.76 & $4.72^{* *}$ & 35.09 & $6.36_{\mathrm{ns}}$ & 1.54 & $1.48_{\mathrm{ns}}$ & 3.80 & $0.84_{\mathrm{ns}}$ & 10.68 & $5.61_{\mathrm{ns}}$ & & \\
\hline Site & 1 & 0.36 & $2.21_{\mathrm{ns}}$ & 0.31 & $0.12_{\mathrm{ns}}$ & 5.45 & $5.23^{*}$ & 0.39 & $0.20_{\mathrm{ns}}$ & 0.52 & $0.54_{\mathrm{ns}}$ & & \\
\hline Treatment $\times$ Site & 3 & 0.10 & $0.60_{\mathrm{ns}}$ & 5.52 & $2.13_{\mathrm{ns}}$ & 1.43 & $1.37_{\mathrm{ns}}$ & 4.51 & $2.30_{\mathrm{ns}}$ & 1.91 & $2.00_{\mathrm{ns}}$ & & \\
\hline Residual & 32 & 0.17 & & 2.59 & & 1.01 & & 1.96 & & 0.95 & & & \\
\hline
\end{tabular}


a) Number of taxa

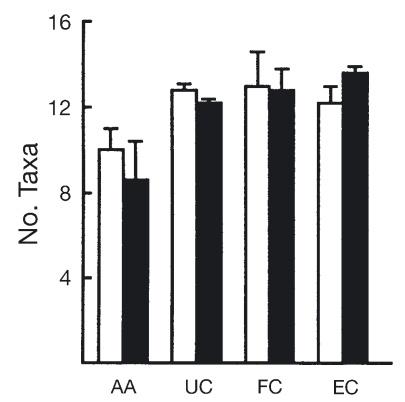

e) Spionidae
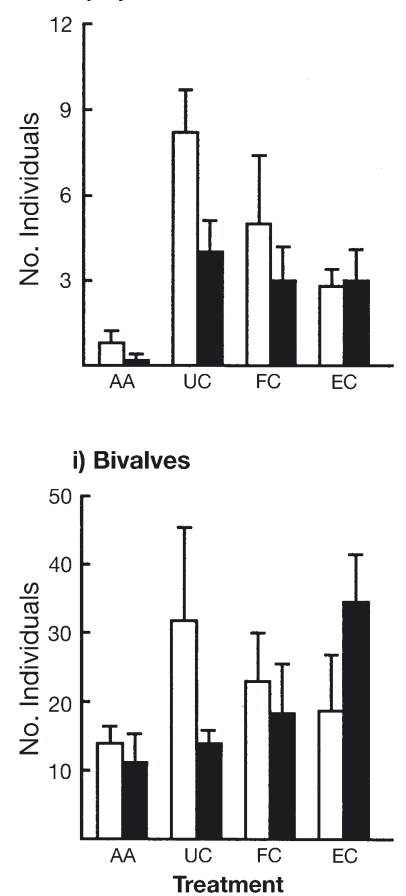

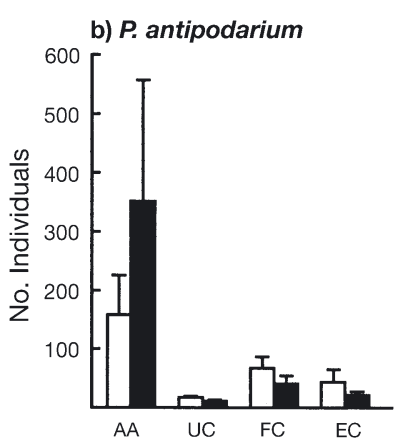

f) Orbiniidae

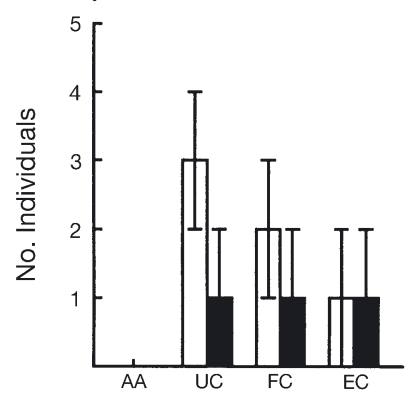

j) Infaunal amphipods

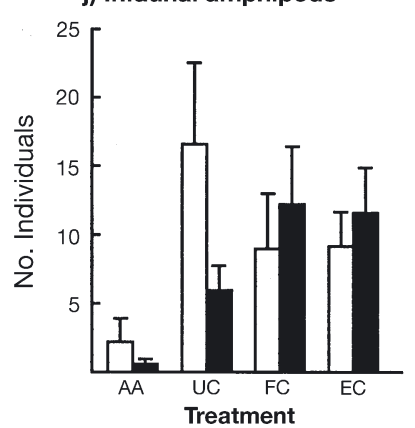

c) Polychaetes

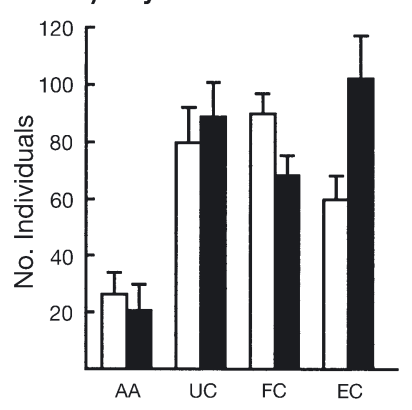

g) Opheliidae

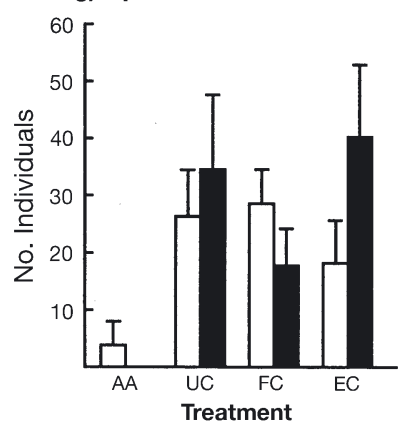

d) Capitellidae

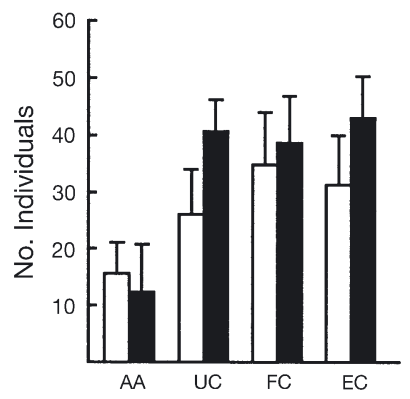

h) Nereididae

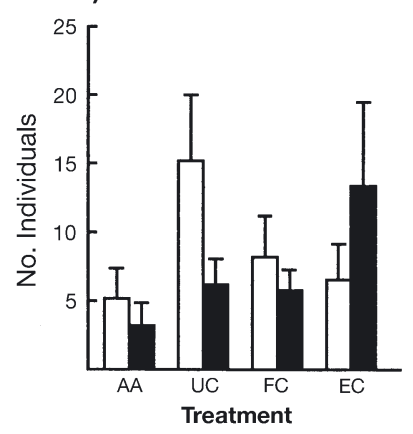

Fig. 4. Mean ( $+\mathrm{SE}_{;} \mathrm{n}=5$ cores) number of species and abundance of selected taxonomic groups of macrobenthos collected from each treatment for each site. Abbreviations and bars as in Fig. 3

most diverse and abundant infauna in the various controls, but were considerably less abundant in plots to which algae had been added. Generally, larger taxa and deeper burrowing forms, including orbinid worms, the bivalve Tellina deltoidalis, the snail Batillaria australis and infaunal amphipods, appeared to have been eliminated from plots to which algae had been added. In contrast, the small ( 3 to $5 \mathrm{~mm}$ ) epifaunal gastropod Potamopyrgus antipodarium was very abundant. These important effects occurred despite the small spatial scale $\left(1 \times 1 \mathrm{~m}^{2}\right.$ plots $)$ and relatively short duration $(3 \mathrm{mo})$ of the experiment.

Multivariate comparison revealed that the macrofauna assemblage of plots to which algae had been added differed distinctly from those in the various controls, mainly due to the relative abundances of a few species. Potamopyrgus antipodarium contributed most to dissimilarities, being present in greater numbers in plots to which algae had been added; however these

gastropods may have been directly introduced with the algae. When Hull (1987) added Enteromorpha spp. to experimental plots, he recorded increased numbers of Hydrobia ulvae, but cautioned that greater abundances could have been due to addition of snails associated with the algae: hydrobiid snails commonly inhabit clumps of drift macroalgae (Soulsby et al. 1982, Hull 1987, Norkko \& Bonsdorff 1996a, Bolam et al. 2000, Norkko et al. 2000), and decomposition of the algae can directly and indirectly provide an abundant food supply for these deposit-feeding snails (see Levinton \& Bianchi 1981, Levinton 1985).

In this study, few dead snails were found, suggesting that individuals transported with the macroalgae were able to avoid anoxic conditions. The abundance of hydrobiid snails can rapidly decline if conditions become anoxic (Norkko \& Bonsdorff 1996a). For example, Norkko \& Bonsdorff (1996a) measured massive declines in the abundance of Hydrobia spp. in re- 
sponse to sediments being covered by macroalgae, whereas snails increased significantly in abundance in experimental compared to control plots within $5 \mathrm{~d}$ of the algae being removed. These authors suggested that the major source of colonisers was from surrounding areas, although they also found large numbers within the algal mat itself (Norkko \& Bonsdorff 1996a). In a later experiment, Norkko et al. (2000) demonstrated that Hydrobia spp. were capable of moving up through the algal canopy to escape anoxic conditions. The apparent addition of snails to assemblages of fauna in plots to which algae had been added emphasises the potential role of drift macroalgae in contributing to colonisation of sediments (see Holmquist 1994, 1997).

Analysis of assemblages omitting data from Potamopyrgus antipodarium revealed differences among algal addition and control treatments that were essentially the same as those when the snail's data were included. Thus, the treatment effect was not solely due to distribution patterns of this snail. Opheliid and capitellid worms also considerably influenced assemblages structure. Opheliids were patchily distributed among replicate samples, but massive declines were recorded under the algal canopy. Capitellid worms were significantly less abundant in plots to which algae had been added, in contrast to studies which recorded increases in abundance of capitellids after addition of macroalgae (e.g. Thrush 1986, Hull 1987, Bolam et al. 2000) and other forms of organic enrichment (Pearson \& Rosenberg 1978).

There are several reasons why one might expect capitellid worms to respond negatively to macroalgae. Generally, the densities of macroalgae added in this experiment were greater than those in the experiments cited above and are likely to have caused extreme anoxic conditions. Dramatic declines in capitellid populations have been observed after severe anoxic conditions have developed in sediments (Tsutsumi 1990). Moreover, the experimental plots in the present study were within a seagrass meadow, and it is well known that seagrass canopies can substantially reduce flow velocities in comparison to that in adjacent areas of unvegetated sediment (Scoffin 1970, Fonseca et al. 1982, 1983, Eckman 1987, Worcester 1995, Boström \& Bonsdorff 2000). Reduced flow velocities could result in greater oxygen deficiency and longer burial of organisms by decomposing algae.

The declines in the abundance of tellinid bivalves and surface-feeding worms (e.g. spionids) after addition of macroalgae were broadly consistent with the results of several other studies (e.g. Ólafsson 1988, Everett 1994, Norkko \& Bonsdorff 1996a). In contrast, Hull (1987) reported increases in tellinid abundance, after macroalgae addition, although most of the indi- viduals he recorded were juveniles. He suggested that the positive results were largely due to algae enhancing the settlement of larval recruits by reducing flow velocities (Hull 1987). As sediments become more anoxic, larger adults are forced to migrate towards the sediment surface, where they are at greater risk of predation (Perkins \& Abbot 1972, Norkko \& Bonsdorff 1996a). Physical interference with feeding behaviour has also been implicated as an important mechanism causing migration of bivalves (Norkko \& Bonsdorff 1996b) and spionid worms (Everett 1994) in areas covered by macroalgae. In the present study, the canopy of macroalgae was in close proximity to the sediment surface, so it is possible that its physical presence in addition to anoxic conditions contributed to declines in components of the benthic fauna.

Declines in above-ground biomass of seagrass were also recorded by Holmquist (1997) and Hauxwell et al. (2001) in response to macroalgae cover. Holmquist $(1994,1997)$ found that small $(0.25 \mathrm{~m}$ diameter), mobile patches of macroalgae added structural complexity to seagrass meadows, but that large (1 $\mathrm{m}$ diameter) stationary patches eliminated underlying seagrasses after 6 mo. Hauxwell et al. (2001) manipulated the canopy height of macroalgae over plots (1 $\mathrm{m}$ diameter) of seagrass, and measured significant declines in aboveground summer production when the algal canopy height was greater than 9 to $12 \mathrm{~cm}$. They attributed declines in density, recruitment, growth-rate and production of the seagrass to reduced light, hypoxic conditions and potentially toxic concentrations of ammonium (Hauxwell et al. 2001).

At the scale of this experiment, the local effects of cover by macroalgae were catastrophic. Although clonal plants, such as seagrasses, are considered to have adapted to dynamic environments (Caraco \& Kelly 1991), recovery after disturbance can be slow (Holmquist 1997, Butler \& Jernakoff 1999, Hauxwell et al. 2001). Even 18 mo after removing macroalgae, Holmquist (1997) measured significantly smaller biomass in experimental than in control plots. Whilst large patches of macroalgae can support a greater diversity and abundance of demersal organisms than the less structurally complex seagrass, these benefits are likely to be offset by their ephemerality and the negative effects of decomposition (Homquist 1997). Few studies have directly examined the consequences of fragmentation of the seagrass habitat, but related studies have shown that changed sizes of patches and spacing between patches of seagrass may subsequently influence the dispersal of animals (Worthington et al. 1991, Doak et al. 1992, Eggleston et al. 1999) and the distribution, abundance and foraging behaviour of predators (Heck \& Thoman 1981, Heck \& Wilson 1987, Skilleter 1994). 
In the present study, it was not possible to determine whether the decline in diversity and abundance of benthic infauna was due to migration from plots to which algae had been added or to mortality. The experimental plots were relatively small, so declines in diversity and abundance may have been due to emigration rather than mortality. Animals may have been able to seek refuge in adjacent patches of habitat. Their ability to survive in this manner could have significant implications in terms of the overall effect of a bloom. If a bloom of algae occurs as small clumps of plants dispersed throughout a seagrass meadow as opposed to an extensive mat, then organisms that are negatively affected could persist by moving into patches between algae-affected areas (Raffaelli et al. 1998). The remnant patches without algae could provide source populations for re-establishment in disturbed sediments. Thus, persistence of the assemblage would be less dependent on a supply of larvae from other habitats.

In a review, Raffaelli et al. (1998) stated that it is still unclear whether there is a direct relationship between increases in macroalgae abundance and concomitant declines in seagrass beds in estuaries around the world. Moreover, few published studies have investigated the effects on assemblages of macrobenthic organisms in seagrass meadows. Through experimental manipulation of the biomass of Enteromorpha intestinalis, this study has demonstrated that overlying mats of macroalgae can cause sizeable gaps in the seagrass canopy. Components of the infauna responded negatively to factors associated with cover and decomposition of the macroalgae, but large numbers of hydrobiid snails (probably introduced together with the algae) were found. Thus, aggregations of drift macroalgae can greatly influence the patterns of distribution and abundance of seagrass and associated fauna. Assemblages of seagrasses generally support greater diversity and abundance of fauna than adjacent areas of unvegetated sediments, so the formation of blooms and subsequent declines in the components of seagrass meadows could have considerable implications for productivity at larger scales. The present study provides quantitative information on changes in assemblages at the small spatial scale relevant to some blooms in the seagrass habitat. Further work is needed to determine the underlying mechanisms and the integrated causes and effects on the scale of an estuary. Quantification of temporal changes and potential rates of recovery of the benthic community is also essential.

Acknowledgements. This research was supported by funds from Wyong Shire Council and the Centre for Research on Ecological Impacts of Coastal Cities in the University of Sydney. For their assistance, we thank M. Bryant, J. Crass, M. A.
Cummins, T. G. Dickinson, P. Mackey, S. R. Murray, D. Tierney, S. Towell, G. Walkerden, N. Wright and K. Yates. A. J. Underwood, A. G. Church, A. R. Davis, A. R. Jones and A. Murray are acknowledged for their help and advice on many aspects of this work. A. J. Underwood, M. G. Chapman, F. Rossi, T. M. Glasby and anonymous reviewers provided comments on the draft manuscript that greatly improved its quality.

\section{LITERATURE CITED}

Anderson EE (1989) Economic benefits of habitat restoration: seagrass and the Virginia hard-shell blue crab fishery. N Am J Fish Manag 9:140-149

Bolam SG, Fernandes TF, Read P, Raffaelli D (2000) Effects of macroalgal mats on intertidal sandflats: an experimental study. J Exp Mar Biol Ecol 249:123-137

Boström C, Bonsdorff E (1997) Community structure and spatial variation of benthic invertebrates associated with Zostera marina (L.) beds in SW Finland. J Sea Res 37:153-166

Boström C, Bonsdorff E (2000) Zoobenthic community establishment and habitat complexity - the importance of seagrass shoot-density, morphology and physical disturbance for faunal recruitment. Mar Ecol Prog Ser 205:123-138

Boström C, Bonsdorff E, Kangas P, Norkko A (2002) Longterm changes of a brackish-water eelgrass (Zostera marina L.) community indicate effects of coastal eutrophication. Estuar Coast Shelf Sci 55:795-804

Brooks RA, Bell SS (2001) Mobile corridors in marine landscapes: enhancement of faunal exchange at seagrass/sand ecotones. J Exp Mar Biol Ecol 264:67-84

Butler A, Jernakoff P (1999) Seagrass in Australia: strategic review and development of an R \& D plan. CSIRO, Victoria

Carcaco T, Kelly CK (1991) On the adaptive value of physiological integration in clonal plants. Ecology 72:81-93

Chapman MG (1998) Relationships between spatial patterns of benthic assemblages in a mangrove forest using different levels of taxonomic resolution. Mar Ecol Prog Ser 162: 71-78

Chapman MG, Underwood AJ, Skilleter GA (1995) Variability at different spatial scales between a subtidal assemblage exposed to the discharge of sewage and two control assemblages. J Exp Mar Biol Ecol 189:103-122

Clarke KR, Warwick RM (1994) Change in marine communities: an approach to statistical analysis and interpretation. Natural Environment Research Council, Swindon

Doak DF, Marino PC, Kareiva PM (1992) Spatial scale mediates the influence of habitat fragmentation on dispersal success: implications for conservation. Theor Popul Biol 41:315-336

Eckman JE (1987) The role of hydrodynamics in recruitment, growth, and survival of Argopecten irradians (L.) and Anomia simplex (d'Orbigny) within eelgrass meadows. J Exp Mar Biol Ecol 106:165-191

Edgar GJ (1990) The influence of plant structure on the species richness, biomass and secondary primary production of macrofaunal assemblages associated with Western Australian seagrass beds. J Exp Mar Biol Ecol 137:215-240

Edgar GJ, Robertson AI (1992) The influence of seagrass structure on the distribution and abundance of mobile epifauna: patterns and process in a Western Australian Amphibolis bed. J Exp Mar Biol Ecol 160:13-31

Edgar GJ, Shaw C (1995) The production and trophic ecology of shallow-water fish assemblages in southern Australia. 3. General relationships between sediments, seagrasses, invertebrates and fishes. J Exp Mar Biol Ecol 194:107-131 
Edgar GJ, Shaw C, Watson GF, Hammond LS (1994) Comparisons of species richness, size-structure and production of benthos in vegetated and unvegetated habitats in Western Port, Vict. J Exp Mar Biol Ecol 176:201-226

Eggleston DB, Elis WE, Etherington LL, Dahlgren P, Posey MH (1999) Organism responses to habitat fragmentation and diversity: habitat colonisation by estuarine macrofauna. J Exp Mar Biol Ecol 236:107-132

Everett RA (1994) Macroalgae in soft-sediment communities: effects on benthic faunal assemblages. J Exp Mar Biol Ecol 175:253-274

Ferrell DJ, Bell JD (1991) Differences among assemblages of fish associated with Zostera capricorni and bare sand over a large spatial scale. Mar Ecol Prog Ser 72:15-24

Fonseca MS, Fisher JS, Zieman JC, Thayer GW (1982) Influence of the seagrass, Zostera marina L., on current flow. Estuar Coast Shelf Sci 15:351-364

Fonseca MS, Zieman JC, Thayer GW, Fisher JS (1983) The role of current velocity in structuring eelgrass (Zostera marina L.) meadows. Estuar Coast Shelf Sci 17:367-380

Gambi MC, Nowell ARM, Jumars PA (1990) Flume observations on flow dynamics in Zostera marina (eelgrass) beds. Mar Ecol Prog Ser 61:159-169

Grady JR (1981) Properties of seagrass and sand flat sediments from the intertidal zone of St Andrews Bay, Florida. Estuaries 4:334-344

Hansen K, Kristensen E (1997) Impact of macrofaunal recolinization on benthic metabolism and nutrient fluxes in a shallow marine sediment previously overgrown with macroalgal mats. Estuar Coast Shelf Sci 45:613-628

Hauxwell J, Cebrián J, Furlong C, Valiela I (2001) Macroalgal canopies contribute to eelgrass (Zostera marina) decline in temperate estuarine ecosystems. Ecology 82:1007-1022

Heck KL, Thoman TA (1981) Experiments on predator-prey interactions in vegetated aquatic habitats. J Exp Mar Biol Ecol 53:125-134

Heck KL, Wilson KA (1987) Predation rates on decapod crustaceans in latitudinally separated seagrass communities: a study of spatial and temporal variation using tethering techniques. J Exp Mar Biol Ecol 107:87-109

Holmquist JG (1994) Benthic macroalgae as a dispersal mechanism for fauna: influence of a marine tumbleweed. J Exp Mar Biol Ecol 180:235-251

Holmquist JG (1997) Disturbance and gap formation in a marine benthic mosaic: influence of shifting macroalgal patches on seagrass structure and mobile invertebrates. Mar Ecol Prog Ser 158:121-130

Holmquist JG (1998) Permeability of patch boundaries to benthic invertebrates: influences of boundary contrast, light level, and faunal density and mobility. Oikos 81:558-566

Hull SC (1987) Macroalgal mats and species abundance: a field experiment. Estuar Coast Shelf Sci 25:519-532

Isaksson I, Pihl L (1992) Structural changes in benthic macrovegetation and associated epibenthic faunal communities. Neth J S Res 30:131-140

James RJ, Lincoln Smith MP, Fairweather PG (1995) Sieve mesh-size and taxonomic resolution needed to describe natural spatial variation of marine macrofauna. Mar Ecol Prog Ser 118:187-198

King RJ, Hodgson BR (1995) Tuggerah Lakes system, New South Wales, Australia. In: McComb AJ (ed) Eutrophic shallow estuaries and lagoons. CRC Press, Boca Raton, FL, p 19-29

Kinney EH, Roman CT (1998) Response of primary producers to nutrient enrichment in a shallow estuary. Mar Ecol Prog Ser 163:89-98

Lavery PS, Lukatelich RJ, McComb AJ (1991) Changes in the biomass and species composition of macroalgae in a eutrophic estuary. Estuar Coast Shelf Sci 33:1-22

Levinton JS (1985) Complex interactions of a deposit feeder with its resources: roles of density, a competitor, and detrital addition in the growth and nutrition and food limitation of deposit feeders. I. The role of microbes in the growth ofmud snails (Hydrobiidae). J Mar Res 39:531-556

Levinton JS, Bianchi TS (1981) Nutrition and food limitation of deposit feeders. I. The role of microbes in the growth of mud snails (Hydrobiidae). J Mar Res 39:531-556

Norkko A, Bonsdorff E (1996a) Population responses of coastal zoobenthos to stress induced by drifting macroalgae mats. Mar Ecol Prog Ser 140:141-151

Norkko A, Bonsdorff E (1996b) Altered benthic preyavailability due to episodic oxygen deficiency caused by drifting algal mats. PSZN I: Mar Ecol 17:355-372

Norkko J, Bonsdorff E, Norkko A (2000) Drifting algal mats as an alternative habitat for benthic invertebrates: species specific responses to a transient resource. J Exp Mar Biol Ecol 248:79-104

Ólafsson EB (1988) Inhibition of larval settlement to a softbottom benthic community by drifting algal mats: an experimental test. Mar Biol 97:571-574

Orth RJ (1973) Benthic infauna of eelgrass, Zostera marina beds. Chesapeake Sci 14:258-269

Orth RJ, Heck JKL, Van Montfrans J (1984) Faunal communities in seagrass beds: a review of influence of plant structure and prey characteristics on predator-prey relationships. Estuaries 7:339-350

Pearson TH, Rosenberg R (1978) Macrobenthic succession in relation to organic enrichment and pollution of the marine environment. Oceanogr Mar Biol Annu Rev 16:229-311

Perkins EJ, Abbott OJ (1972) Nutrient enrichment and sandflat fauna. Mar Pollut Bull 3:70-72

Peterson CH (1982) Clam predation by whelks (Busycon spp.): experimental tests of the importance of prey-size, prey density and seagrass cover. Mar Biol 66:159-170

Peterson CH, Summerson HC, Duncan PB (1984) The influence of seagrass cover on population structure and individual growth rate of a suspension-feeding bivalve, Mercenaria mercenaria. J Mar Res 42:123-138

Raffaelli DG, Raven JA, Poole LJ (1998) Ecological impact of green macroalgal blooms. Oceanogr Mar Biol Annu Rev 36:97-125

Roberts DE (2001) Tuggerah Lakes estuary process study. Wyong Shire Council, Wyong, NSW

Scoffin TP (1970) The trapping and binding of subtidal carbonate sediments by marine vegetation in Bimini Lagoon, Bahamas. J Sediment Petrol 40:249-273

Sfriso A, Pavoni B, Marcomini A, Orio AA (1992) Macroalgae, nutrient cycles and pollutants in the lagoon of Venice. Estuaries 15:517-528

Shepherd SA, McComb AJ, Bulthuis DA, Neverauskas V, Steffensen DA, West R (1989) Decline of seagrasses. In: Larkum AWD, McComb AJ, Shepherd SA (eds) Biology of seagrasses: a treatise on the biology of seagrasses with special reference to the Australian region. Elsevier, Amsterdam, p 346-393

Skilleter GA (1994) Refuges from predation and the persistence of estuarine clam populations. Mar Ecol Prog Ser 109:29-42

Soulsby PG, Lowthian D, Houston M (1982) Effects of macroalgal mats on the ecology of intertidal mudflats. Mar Pollut Bull 13:162-166

Sogard SM, Able KW (1991) A comparison of eelgrass, sea lettuce macroalgae and marsh creek habitats for epibenthic fishes and decapods. Estuar Coast Shelf Sci 33:501-519 
Stamps JA, Buechner M, Krishnan VV (1987) The effects of edge permeability and habitat geometry on emigration from patches of habitat. Am Nat 129:533-552

Stoner AW (1980) The role of seagrass biomass in the organisation of benthic macrofaunal assemblages. Bull Mar Sci 30:537-551

Thrush SF (1986) The sublittoral macrobenthic community structure of an Irish sea-lough: effect of decomposing accumulations of seaweed. J Exp Mar Biol Ecol 96:199-212

Tsutsumi H (1990) Population persistence of Capitella sp. (Polychaeta; Capitellidae) on a mud flat subject to environmental disturbance by organic enrichment. Mar Ecol Prog Ser 63:147-156

Underwood AJ (1981) Techniques of analysis of variance in experimental marine biology and ecology. Oceanogr Mar Biol Annu Rev 19:513-605

Underwood AJ, Chapman MG (1998) A method for analysing spatial scales of variation in composition of assemblages. Oecologia 117:570-578

Virnstein RW, Carbonara PA (1985) Seasonal abundance and distribution of drift algae and seagrasses in the mid-Indian Lagoon, Florida. Aquat Bot 23:67-82

Walker KF (1998) Molluscs of inland waters. In: Beesley PL, Ross GJB, Wells A (eds) Mollusca: the southern synthesis.

Editorial responsibility: John Gray (Contributing Editor), Oslo, Norway
Fauna of Australia, Vol 5, Part A xvi. CSIRO, Melbourne, p 59-65

Warwick RM (1988) Analysis of community attributes of the macrobenthos of Frierfjord/Langesundfjord at taxonomic levels higher than species. Mar Ecol Prog Ser 46:167-170

Warwick RM, Clarke KR (1993) Increased variability as a symptom of stress in marine communities. J Exp Mar Biol Ecol 172:215-226

Wiens JA (1992) Ecological flows across landscape boundaries: a conceptual overview. In: Hansen AJ, di Castro F (eds) Landscape boundaries: consequences for biotic diversity and ecological flows. Springer-Verlag, New York, p 217-235

Williams Cowper S (1978) The drift algae community of seagrass beds in Redfish Bay, Texas. Contrib Mar Sci 21: 125-132

Winer BJ, Brown DR, Michels KM (1991) Statistical principles in experimental design. McGraw-Hill, New York

Worcester SE (1995) Effects of eelgrass beds on advection and turbulent mixing in low current and low shoot density environments. Mar Ecol Prog Ser 126:223-232

Worthington DG, Westoby M, Bell JD (1991) Fish larvae settling in seagrass:effects of leaf density and an epiphytic alga. Aust J Ecol 16:289-293

Submitted: January 10, 2003; Accepted: November 4, 2003 Proofs received from author(s): January 12, 2004 